\title{
NEPALESE NULL AMELY MALES AND THEIR Y-HAPLOTYPES
}

\author{
Dinesh K. Jha*, Jiwan Pd. Rijal* and Nirajan T. Chhetri* \\ *National Forensic Science Laboratory, Khumaltar, Lalitpur, Nepal.
}

\begin{abstract}
Amelogenin is the well-liked process for sex typing in recent days. Exceptional failures to amplify AMELY accurate products can cause erroneous gender identification consequence male samples mistakenly identified as females. A total of 9 null AMELY males were noticed in 200 males of 72 Nepalese surnames by means of $4.5 \%$ frequency. No amplification of DYS458 Marker in all null AMELY males but great sharing of amplified Y STR alleles among them is a probable sign of the general phylogenetic origin.
\end{abstract}

Key words: Forensic; Gender determination; Amelogenin; Null AMELY; Y-STR haplotypes etc.

\section{INTRODUCTION:}

A precise gender determination is the crucial not only in forensic and medical science but also in other field. Amelogenin system is the most popular method for sex-typing today ${ }^{10}$. Human gender identification, based on the amelogenin gene has important applications in prenatal diagnosis $^{42}$, forensic casework ${ }^{39}$, archaeological analysis ${ }^{38,17}$, preimplantation, DNA databasing, blood sample storage as well as in paternity testing. The amelogenin gene produces a protein important in the development of the tooth enamel matrix $^{9}$. The human amelogenin gene sequenced by Nakahori et al. ${ }^{28,29}$ has two homologous alleles, one on the $\mathrm{X}$ chromosome (AMELX) and the other on the Y chromosome $(\mathrm{AMELY})^{28}$ differing in both size and sequence. The human AMELX gene has a size of $2872 \mathrm{bp}$ and is located at 11.075 $\mathrm{Mb}$ on the X chromosome between positions Xp22.1-p22.3 (GenBank accession number M55418) while the human AMELY-gene has a size of $3272 \mathrm{bp}$ and is located at $6.781 \mathrm{Mb}$ on the Y chromosome at Yp11.2 (GenBank accession number M55419; $)^{6,11,28,29}$. Regions on this gene that are sufficiently conserved are amplified for simultaneous detection of the $\mathrm{X}$ and $\mathrm{Y}$ alleles in gender identification procedures. The amelogenin sex test is based on the identification of single copy X and Y-homologous regions. It was first described for PCR by Nakahori et al. ${ }^{28,29}$. Several PCR primer sets have been developed to use this gene as a sex test $1,2,6,15,16,18,39$. The most commonly used amelogenin PCR-based sex test is the one described by Sullivan et al. ${ }^{39}$ in which primers flank a 6 bp deletion within intron 1 of the homologues resulting in 106 and 112 bp PCR products from the X-and Y-chromosome respectively. Since $\mathrm{X}$ and $\mathrm{Y}$ specific sequences together can be amplified in a single reaction using single primer, $\mathrm{X}$ chromosome product itself acts as an internal positive control $^{10}$. Though Amelogenin is an effective method for sextyping biological samples in most cases; the results are not full proof ${ }^{10}$. Failures to amplify sex chromosome, particularly AMELY specific products can result in incorrect gender identification, in which male samples falsely identified as females. AMELX dropout has also been observed in males in which only the AMELY amplicon is present ${ }^{35}$. AMELY deletion males are of phenotypic interest. Since such males lack the Amelogenin Y gene itself, and may also lack other nearby genes on Yp hence study of such males could throw light on the selective influence that the absence of any such genes might have ${ }^{20}$. We reported 9 null AMELY males out of 200 male samples analyzed from 72 different surnames of Nepal. Therefore calculated null AMELY was $4.5 \%$. The reality of AMELY dropouts reinforces the essential to analyzed additional sexing markers like SRY, Y-STR and STS for consistent gender determination. Null AMELY males DNA samples were further subjected for Y-STR amplification to determine the nature of Y STR haplogroup.

\section{MATERIALS AND METHODOLOGY:}

Samples: A total of 200 phenotypic recognized Nepalese male samples (stated in the identification form) received from different court and personel concern for the intention of DNA based paternity issues were the source of this study. All the samples were collected and stored as dried bloodstains on FTA classic card. DNA was purified from $1.2 \mathrm{~mm}$ diameter circles of bloodstained FTA papers using FTA purification reagent and $\mathrm{TE}^{-1}$ buffer (10mM Tris-HCl, $0.1 \mathrm{mM}$ EDTA, $\mathrm{PH}$ 8.0) in accordance with the manufacturer's recommendations.

Author for Correspondence: Dinesh k. jha, Senior Scientific Officer, National Forensic Science Laboratory, Nepal. Email: dineshkjha@hotmail.com 
Amelogenin Multiplex Typing: The purified and dried FTA punch cards were subjected to PCR for DNA amplification using the AmpF-!STR ${ }^{\circledR}$ Identifiler ${ }^{\circledR}$ PCR Amplification Kit (Applied BioSystems, Foster City, CA, USA) containing the 15Autosomal STR markers with amelogenin marker for gender determination. Procedures followed were adopted from standard manufacture's protocol ${ }^{4}$ with minor alterations. Each AmpF-!STR ${ }^{\circledR}$ Identifiler ${ }^{\circledR}$ PCR Amplification reaction contained $5 \mu \mathrm{l}$ AmpF-!STR ${ }^{\circledR}$ PCR reaction mix, $2.5 \mu \mathrm{l}$ AmpF!STR ${ }^{\circledR}$ Identifiler ${ }^{\circledR}$ primer set, $0.5 \mu \mathrm{l}$ AmpF-!STR ${ }^{\circledR}$ AmpliTaq Gold $^{\circledR}$ DNA Polymerse and $4 \mu$ l of deionized water to a final volume of $12 \mu \mathrm{l}$. Amplification was performed in a ABI GeneAmp $^{\circledR} 9700$ thermal cycler employing the following conditions: 25 cycles at $95^{\circ} \mathrm{C}$ for 11 minutes (initial incubation); $94^{\circ} \mathrm{C}$ for 1 minute (denature); $59^{\circ} \mathrm{C}$ for 1 minute (anneal), $72^{\circ} \mathrm{C}$ for 1 minute (extend), $60^{\circ} \mathrm{C}$ for 1 hour (final extension) and 4 $25^{\circ} \mathrm{C}$ for final step. Genotyping of the amplified PCR products was performed on an ABI PRISM ${ }^{\circledR} 310$ Genetic Analyzer (Applied BioSystems, Foster City, CA, USA). Briefly, $0.5 \mu \mathrm{l}$ aliquots of PCR product was mixed with $24.5 \mu \mathrm{l}$ of $\mathrm{Hi}-\mathrm{Di}^{\mathrm{TM}}$ Formamide and $0.5 \mu \mathrm{l}$ of GeneScan ${ }^{\mathrm{TM}}-500 \mathrm{LIZ}^{\mathrm{TM}}$ Size standard. One tube was prepared additionally as above, but $1 \mu$ of AmpF-!STR ${ }^{\circledR}$ Identifiler ${ }^{\circledR}$ Allelic Ladde was substituted instead of sample. Samples were denaturated at $95^{\circ} \mathrm{C}$ for 3 minute and snap-cooled for 3 minutes. Electrophoresis separation was carried out with a $47 \mathrm{~cm}$ x $50 \mu \mathrm{m}$ capillary. Samples were routinely electrokinetically injected for 5 seconds followed by a 28 minutes run at a constant voltage of $15 \mathrm{kV}$ and temperature of $60^{\circ} \mathrm{C}$. The separation medium was the Performance Optimized Polymer 4 (POP-4). The run buffer was a 1:10 dilution of Buffer (10X) with EDTA. Allele designations of Amelogenin together with 15 autosomal STR markers were determined from the electropherograms by comparing with AmpF-!STR ${ }^{\circledR}$ Identifiler ${ }^{\circledR}$ Allelic Ladder using GeneMapper ID v3.2 software (Applied BioSystems).

Gender identification with Y-STR: AMELY dropout males samples were further subjected for Y-STR amplification, using the AmpF-!STR ${ }^{\circledR}$ Y filer ${ }^{\mathrm{TM}}$ PCR Amplification Kit (Applied BioSystems, Foster City, USA), following the manufacturer user's manual $^{5}$. Briefly, Y filer enables the simultaneous amplification of 16 locus on the Y-chromosome, namely DYS456, DYS389I, DYS390, DYS389II, DYS458, DYS19, DYS385a/b, DYS393, DYS391, DYS439, DYS635, DYS392, Y GATAH4, DYS437, DYS438 and DYS448. The amplified PCR products were analyzed using an ABI Prism 310 Genetic Analyzer and detailed alleles determined with GeneMapper ID v3.2. .

\section{RESULTS AND DISCUSSION:}

Amelogenin gene based gender identification is not fully reliable test and occasionally shows controversial cases. Males were erroneously typed as females due to lack of Yspecific amelogenin amplification. Such result in dire if used in cases of criminal investigation, gender identification in the setting of prenatal diagnosis or in identifying human remains from mass disasters etc. The amelogenin included in AmpF!STR ${ }^{\circledR}$ Identifiler ${ }^{\circledR}$ Allelic Ladder yields peaks of $107 \mathrm{bp}$ and 113bp i.e. former peak from the $\mathrm{X}$ chromosome and the latter from the Y chromosome. As expected, the majority males exhibit two amelogenin peaks and female contained one peak, corresponding to the $\mathrm{X}-\mathrm{Y}$ and $\mathrm{X}$ chromosomes, respectively with a standard amelogenin test. On the contrary, the DNA of a few males amplified at nearly 107bp (X) but failed to amplify at 113bp (Y). Additionally, the natures of this 107bp peak are similar to that of the female sample (Fig1).
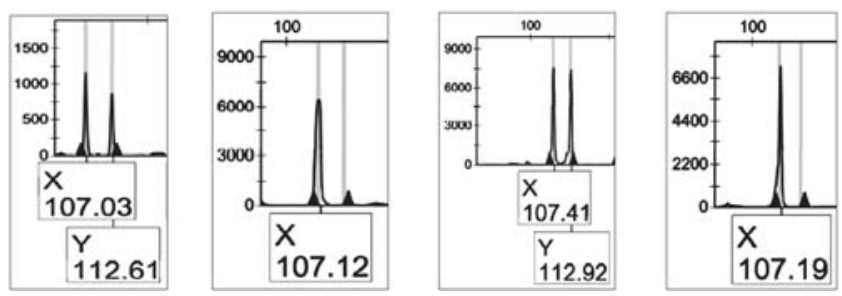

Fig1: Amelogenin amplification (left to right): Allelic ladder, Normal female, Normal male and null AMELY male.

The existence of AMELY null allele had been reported globally. The total of 200 males belongs to different 72 Nepalese surnames were studied in this study. The numerical surnamewise details of these are; one each sample from Ansari, Badu, Bhatt, Budha, Chaudhary, Dahal, Dangi, Dev, Dubey, Gelal, Giri, Hussain, Kewat, Lama, Murav, Pariyar, Pun, Purja, Rajbanshi, Raskoti, Sah, Shah and Thakur, two each samples from Ale, Baraili, Basnet, Bhandari, Bhujel, Chonzom, Ghale, KC, Karki, Kohar, Koirala, Kumal, Lonia, Marasini, Mishra, Miya, Nakarmi, Ojha, Pasarwal, Pradhan, Regmi, Rijal, Sapkota, Tamang, Udas, Uprety and Yari, three each samples from Kurmi, Majhi, Paudel and Upadhyay, four each samples from Ahir, Chetri, Malla, Pandey, Rana, Shahi (Khadki) and Sharma, five each samples from Adhikari, Gautam, Ghimire, Pokhrel and Tharu, six each samples of Jha, Rai and Thapa, seven sample of Khadka, nine sample from Shrestha and 24 sample from Gurung. In this study, drop out of the AMELY was detected in 9 out of 200 phenotypically normal Nepalese males. Details of null AMELY males are cited in table 1. Paternal inheritance of null AMELY as well observed in donor of sample 65001B and 67018B. This reason was confirmed by AmpF-!STR $®$ Identifiler ${ }^{\circledR}$ PCR Amplification Kit and AmpF!STR ${ }^{\circledR}$ Y filer ${ }^{\mathrm{TM}}$ PCR Amplification Kit. The percent of null AMELY males in the Nepalese population (4.5\%) in this study is lower than that observed by Santosh et al. ${ }^{33}$ in Sri Lankan males ( $8 \%$ i.e. 2 of 24) and Cadenas et al. ${ }^{12}$ in the Kathmandu population (6.49\% i.e. 5 of 77) but higher than that of males observed in India (3.57\% ) and Malaysia (0.88\%) by Chang et al. ${ }^{13}$, India $(0.23 \%$ i.e. 10 of 4,257$)$ by Kashyap et al. ${ }^{22}$, India (1.85\% i.e. 5 of 270 ) by Thangaraj et al. ${ }^{40}$, Nepal (1.2\% i.e. 9 of 769) by Parkin et al. ${ }^{30}$, Israel (1.04\% i.e. 1 of 96) by Michael and Brauner ${ }^{26}$, Spain (0.13\% i.e. 1 of 768$)$ by Bosch et al. ${ }^{7}$, Austria $\left(0.018 \%\right.$ i.e. 5 of 28,182) by Steinlechner et al. ${ }^{37}$ and Italy $(0.008 \%$ i.e. 1 of 13,000$)$ by Lattanzi et al. ${ }^{24}$. The existence of AMELY dropouts in South East Asia emphasizes the needs to be cautious when interpreting AMELY sexing tests. It reinforces the necessity to include other sexing markers for gender determination in our regional populations ${ }^{41}$. It has been suggested that multiple Y chromosome markers should be analyzed for reliable gender identification ${ }^{22}$ in cases where 
Table1: Comparisons of Y-STR haplotypes of null AMELY males.

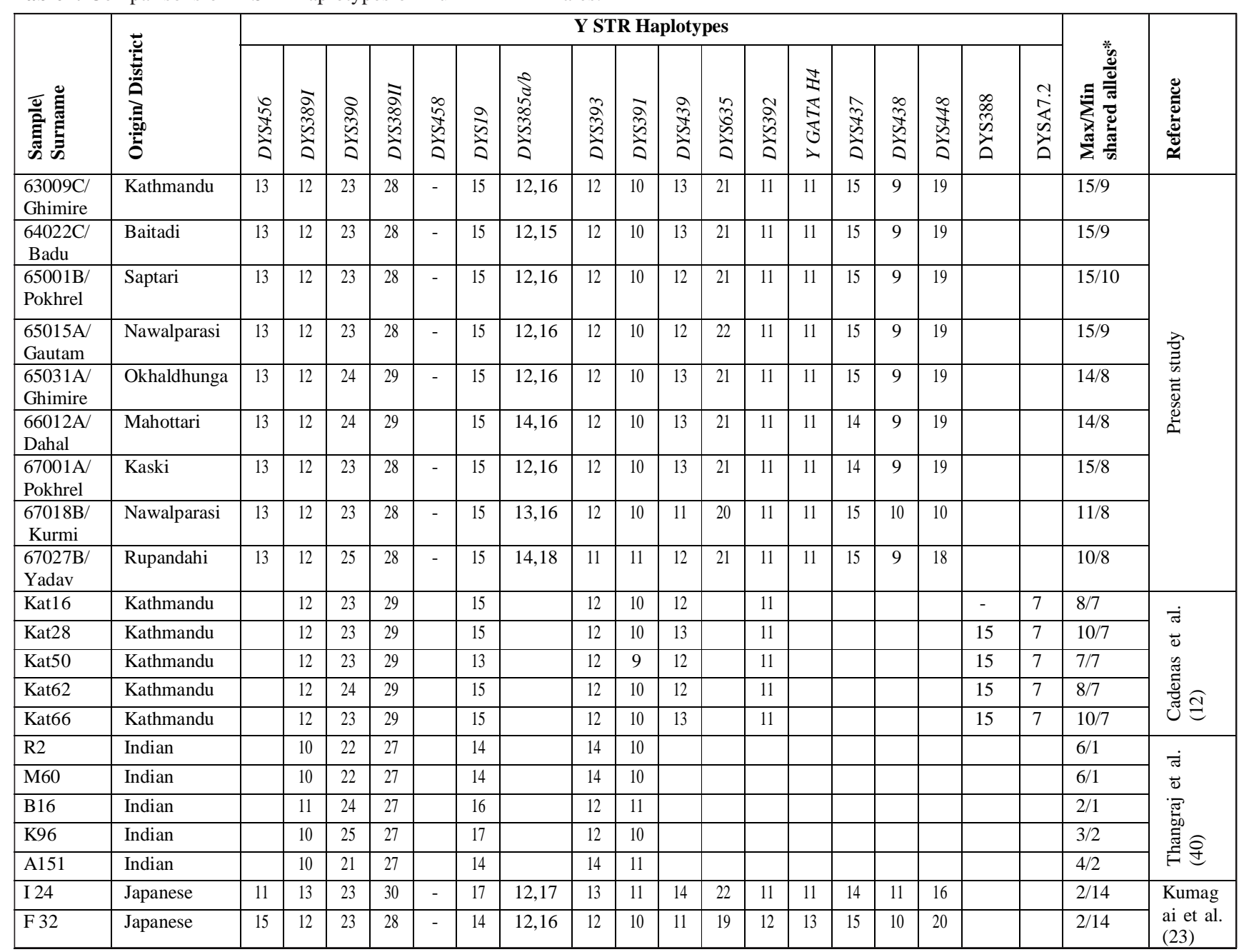

*: Comparisons made between each individuals within each study.

-: No amplification.

sex identification is critical. Thangraj et al (2002) advise the inclusion of supplementary $\mathrm{Y}$ chromosome markers such as SRY, STR, STS and/or other Y chromosome markers in the existing multiplex STR kits for gender identification.

A primer binding site mutation on AMELY ${ }^{32,34,35}$ or large-scale deletions in the Y-chromosomal homologue ${ }^{24,25,33,37,40}$ are basis for frequently failure of AMELY amplification. It is rarely due to mutations in the primer-annealing region ${ }^{32,34}$ rather a common mutation pattern involves the complete deletion of AMELY. Primarily, two Sri Lankan males were recognized who lacked AMELY through a deletion on the short arm of the $Y$ chromosome ${ }^{34}$. Afterward, AMELY null males with deletion in Yp11.2 region have been found in various populations ${ }^{12,19,22,24,25,41}$. The widespread use of the amelogenin PCR assay provides strong ascertainment of males with apparent interstitial AMELY deletions ${ }^{20}$ and the availability of the near-complete sequence of a Y chromosome ${ }^{36}$ allows the investigation of the mutational mechanism(s) underlying deletions. Application of malespecific markers like SNPs, STRs, STSs becomes useful in order to delineate the breakpoints of the deletions as well as assess the overall integrity of the Y-Chromosome ${ }^{12}$. Similarly, in order to determine whether amelogenin null profiles caused by primer mismatch due to a point mutation affecting the oligonucleotide binding site(s) targeted Primers, amplification of null amelogenin samples with a different amelogenin primer pair (like AMEL-2F/3R) is benefecial ${ }^{12}$. However, specific reason of AMELY dropout in males could not be determined in the present study.

Amplification of Y-STR indicates the basis of failure of amelogenin typing i.e. either due to mutation in the primerbinding region ${ }^{8}$ or due to deletions in the amelogenin region (11.2p) on the Y-chromosome ${ }^{37}$. Y-STR analysis provides further haplotyping resolution, and clustering of haplotypes within a haplogroup can support the idea of common ancestry ${ }^{20}$. The successful amplification of 15 distinct Ychromosomal STR Markers was observed in all null AMELY samples in the present study. But every one of these samples failed to amplify DYS458 Locus. AMELY null males with no amplification of DYS458 Marker have been found in various populations (Chang et al. 2007; Jobling et al. 2007; Kumagai et al. 2010). DYS458 ${ }^{31}$ is composed of a polymorphic tetra (GAAA) nucleotide repeat motif and is located at position $7.93 \mathrm{Mb}$ on $\mathrm{Yp}^{23}$. Null alleles at this locus have been linked 
with amelogenin allele negative men, caused by large scale (>1 Mb) deletions ${ }^{14}$. It often corresponds to specific Ychromosome binary haplogroup affiliation ${ }^{12}$ suggestive of common Y-chromosome lineal ancestries within STR haplotype based data sets ${ }^{27}$.

A comparative Y-STR profile of null AMELY males with other study is listed in the Table 1. With the exception of the work by Kumagai et al. ${ }^{23}$ in which both null AMELY males possess very different Y- STR haplotypes, comparisons of the Y-STR profiles of null AMELY males for the remaining publications listed in Table 1 displays a greater proportion of similarity within each study. The Y-STR profiles of null AMELY males were sharing a maximum of fifteen alleles and a minimum of eight in this study. The facts that the 5 samples reveal incredibly parallel haplotypes by sharing maximum of 15 alleles. The proportion of sharing alleles within the mountain based surname samples is significantly greater than those samples belong to Terai based surnames. Sharing of maximum 15 alleles among mountain based surname persons in contrast to 11 alleles of Terai based person (Sample 67018B and $67027 \mathrm{~B}$ ) is the sign of well cultural and geographical diversity and demarcation between them. Great sharing of alleles (upto 7 out of 8 similar Loci) between samples of this study with Cadenas et al. (2006) strength the possibility of similar phylogenetic origin. Samples belong to the same Y haplogroup and exhibit identical or very similar Y-STR haplotypes suggests the deletions possibly occurred in the same paternal lineage ${ }^{12}$.

\section{CONCLUSION:}

The present result of 9 null AMELY males out of a total of 200 samples with the frequency of $4.5 \%$ in Nepalese populations accentuates the need to routinely employ SRY, Y-STR like markers for gender determination in order to obtain an accurate set of inclusion criteria especially in criminal investigations and individual identification. Dropout of similar locus and highly sharing of Y-STR alleles (upto15 alleles in 5 cases) among sample gives general phylogenetic context among them. Applications of specific additional primers like AMEL2F/3R as well Y - specific STSs, SNPs markers enlighten the factual scenerio.

\section{AUTHORS' CONTRIBUTIONS:}

Dinesh k. jha contributed in designing and carrying out of experiments, data analyses and interpretation as well as manuscript preparation. Jiwan P. Rijal provided significant information in manuscript preparation. Nirajan T. Chhetri contributed considerable in execution of experiments. All authors read and approved the final manuscript.

\section{ACKNOWLEDGEMENTS:}

The authors are thankful to Ms Bhinu Shova Tuladhar, Executive Director of National Forensic Science Laboratory, Nepal for her valuable suggestion. We are also thankful to Mr. Basant Raj Pokhrel, Scientific Assistant of this lab for his cooperation in experiment execution.

\section{REFERENCES:}

1. Akane, A., Seki, S., Shiono, H., Nakamura, H., Hasegawa, M., Kagawa, M., Matsubara, K., Nakahori, Y., Nagafuchi, S. and Nakagome, Y. 1992. Sex determination of forensic samples by dual PCR amplification of an X-Y homologous gene. Forensic Sci Int. 52: 143-148

2. Akane, A., Shiono, H., Matsubara, K., Nakahori, Y., Seki, S., Nagafuchi, S., Yamada, M., Nakagome, Y. 1991. Sex identification of forensic specimens by polymerase chain reaction (PCR): two alternative methods. Forensic Sci Int. 49: 81-88

3. Alves, C., Coelho, M., Rocha, J., Amorim, A. 2006. The amelogenin locus displays a high frequency of $\mathrm{X}$ homologue failures in São Tomé island (West Africa). Int Cong Ser. 1288: 271-273

4. Applied Biosystems. 2001. AmpF-!STR Identifiler ${ }^{\mathrm{TM}}$ PCR Amplification Kit, User's manual.

5. Applied Biosystems. 2005. AmpF-!STR ${ }^{\circledR}$ Y filerTM PCR Amplification Kit, User's manual, USA.

6. Bailey, D.M., Affara, N.A., Ferguson-Smith, M.A. 1992. The $\mathrm{X}-\mathrm{Y}$ homologous amelogenin maps to the short arms of both the $\mathrm{X}$ and $\mathrm{Y}$ chromosomes and is highly conserved in primates. Genomics. 14: 203-205

7. Bosch, E., Lee, A.C., Calafell, F., Arroyo, E., Henneman, P., de Knijff, P., Jobling, M.A. 2002. High resolution Y chromosome typing: 19 STRs amplified in three multiplex reactions. Forensic Sci Int. 125: 42-51

8. Boutrand, L., Egyed, B., Füredi, S., Mommers, N., Mertens, G., Vandenberghe, A. 2001. Variations in primer sequences are origin of allele drop-out at loci D13S317 and CD4. Int J Legal Med. 114: $295-297$

9. Buel, E., Wang, G., Schwartz, M. 1995. PCR amplification of animal DNA with human X-Y amelogenin primers used in gender determination. J Forensic Sci. 40: 641-4.

10. Butler John, M. 2005. Forensic DNA typing, Biology, Technology, and Genetics of STR Markers. Second edition, Elsevier Academic press, USA.

11. Butler John M. 2006. Genetics and Genomics of core short tandem repeat loci used in Human identity testing. J. forensic sci. 51(2): 253-265

12. Cadenas, A.M., Regueiro, M., Gayden, T., Singh, N., Zhivotovsky, L.A., Underhill, P.A., Herrera, R.J. 2006. Male amelogenin dropouts: phylogenetic context, origins and implications. Forensic Sci Int. 166: 155-163.

13. Chang, Y.M., Burgoyne, L.A., Both, K. 2003. Higher failures of amelogenin sex test in an Indian population group. J Forensic Sci. 48: 1309-1313.

14. Chang, Y.M., Perumal, R., Keat, P.Y., Yong, R.Y.Y., Kuehn, D.L., Burgoyne, L. 2007. A distinct Y-STR haplotype for amelogenin negative males characterized by a large Yp11.2 (DYS458-MSY1AMELY) deletion. Forensic Sci Int. 166: 115-120

15. Codina, A.E., Niederstätter, H., Parson, W. 2009. “GenderPlex” a PCR multiplex for reliable gender determination of degraded human DNA samples and complex gender constellations Int $\mathrm{J}$ Legal Med 123:459-464

16. Faerman, M., Filon, D., Kahila, G., Greenblatt, C.L., Smith, P., Oppenheim, A. 1995. Sex identification of archaeological human remains based on amplification of the $\mathrm{X}$ and $\mathrm{Y}$ amelogenin alleles. Gene. 167: 327-332. 
17. Faerman, M., Kahila, G., Smith, P., Greenblatt, C., Stager, L. Filon, D. and Oppenheim, A. 1997. DNA analysis reveals the sex of infanticide victims. Nature. 385: 212-213.

18. Haas-Rochholz, H., Weiler, G. 1997. Additional primer sets for an amelogenin gene PCR-based DNA-sex test Int J Legal Med. 110: 312-315.

19. Henke, J., Henke, L., Chatthopadhyay, P., Kayser, M., Dulmer, M., Cleef, S., Poche, H., Felske-Zech, H. 2001. Application of Y-chromosomal STR haplotypes to forensic genetics. Croat Med J. 42:292-297.

20. Jobling, M.A., Lo, ICC., Turner, D.J., Bowden, G.R., Lee, A.C., Xue, Y., Carvalho-Silva, D., Hurles, M.E., Adams, S.M., Chang, Y.M., Kraaijenbrink, T., Henke, J., Guanti, G., McKeown, B., van Oorschot RAH, Mitchell, R.J, de KnijV P., Tyler-Smith, C., Parkin, E.J. 2007. Structural variation on the short arm of the human Y chromosome: recurrent multigene deletions encompassing Amelogenin Y. Human Molecular Genetics 16:307-316

21. Kao Li-Gi, Tsai Li-Chin, Lee J Chun-I, Hsieh Hsing-Mei (2007) Controversial cases of human gender identification by amelogenin test: Forensic Science Journal; 6 (2) : 69-71

22. Kashyap VK, Sahoo S, Sitalaximi T, Trivedi R (2006) Deletions in the Y-derived amelogenin gene fragment in the Indian population. BMC Medical Genetics 7:37

23. Kumagai R, Sasaki Y, Tokuta T, Biwasaka H, Matsusue A, Aoki Y, Dewa K (2010) Distinct breakpoints in two cases with deletion in the Yp11.2 region in Japanese population. Hum Genet 127:537-543

24. Lattanzi W, Di Giacomo M, Lenato GM, Chimienti G, Voglino G (2005) A large interstitial deletion encompassing the amelogenin gene on the short arm of the Y chromosome. Hum Genet 116:395-401

25. Michael A, Brauner P (2004) Erroneous gender identification by the amelogenin sex test. J Forensic Sci 49:258-259

26. Mitchell RJ, Kreskas M, Baxter E, Buffalino L, Van Oorschot RAH (2006) An investigation of sequence deletions of amelogenin (AMELY), a Y-chromosome locus commonly used for gender determination. Ann Hum Biol 33:227-240

27. Myres NM, Ekins JE, Lin AA, L. Cavalli-Sforza L, Woodward SR, Underhill PA (2007): Y-chromosome Short Tandem Repeat DYS458.2 Non-consensus Alleles Occur Independently in Both Binary Haplogroups J1-M267 and R1b3- M405 : Croat Med J. 48:450-9

28. Nakahori Y, Hamano K, Iwaya M, Nakagome Y (1991b) Sex identification by the polymerase chain reaction using $\mathrm{X}-\mathrm{Y}$ homologous primers. Am J Med Genet 39: 472-473

29. Nakahori Y, Takenaka O, Nakagome Y (1991a) A human X-Y homologous region encodes amelogenin. Genomics 9 :264-269
30. Parkin EJ, Kraayenbrink T, Opgenort JPML, van Driem GL, Tuladhar NM, de Knijff P, Jobling MA (2007) Diversity of 26locus Y-STR haplotypes in a Nepalese population sample: Isolation and drift in the Himalayas. Forensic Sci Int 166:176181

31. Redd AJ, Agellon AB, Kearney VA, Contreras VA, Karafet T, Park H (2002) Forensic value of 14 novel STRs on the human Y chromosome. Forensic Sci Int. 130:97-111

32. Roffey PE, Eckhoff CI, Kuhl JL (2000) A rare mutation in the amelogenin gene and its potential investigative ramifications. J Forensic Sci 45:1016-1019

33. Santos FR, Pandya A, Tyler Smith C (1998) Reliability of DNA -based sex tests. Nat Genet 18:103

34. Shadrach B, Commane M, Hren C, Warshawsky I (2004) A rare mutation in the primer binding region of the amelogenin gene can interfere with gender identification. J Mol Diagn 6:401405

35. Shewale JG, Richey SL, Sinha SK (2000) Anomalous amplification of the amelogenin locus typed by AmpFISTR Profiler Plus amplification kit. Forensic Science Communications 2, Available at http: // www.fbi.gov/hq/lab/fsc/backissu/oct2000/shewale.htm

36. Skaletsky H, Kuroda Kawaguchi T, Minx PJ, Cordum HS, Hillier L, Brown LG, Repping S, Pyntikova R, Ali J, Bieri T (2003) The male-specific region of the human Y chromosome: a mosaic of discrete sequence classes. Nature, 423, 825-837

37. Steinlechner M, Berger B, Niederstatter H, Parson W (2002) Rare failures in the amelogenin sex test. Int J Legal Med 116:117120

38. Stone AC, Milner GR, Pa“a”bo S and Stoneking M (1996) Sex determination of ancient human skeletons using DNA. Am. J. Phys. Anthropol., 99, 231-238

39. Sullivan KM, Mannucci A, Kimpton CP, Gill P (1993) A rapid and quantitative DNA sex test: fluorescence-based PCR analysis of $\mathrm{X}-\mathrm{Y}$ homologous gene amelogenin. Biotechniques 15 : 636641

40. Thangaraj K, Reddy AG, Singh L (2002) Is the amelogenin gene reliable for gender identification in forensic casework and prenatal diagnosis? Int J Legal Med 116:121-123

41. Yong RYY, Gan LSH, Chang YM, Yap EPH (2007) Molecular characterization of a polymorphic 3-Mb deletion at chromosome Yp11.2 containing the AMELY locus in Singapore and Malaysia populations. Hum Genet 122:237-249

42. Zhu B, Sun QW, Lu YC, Sun MM, Wang LJ and Huang XH (2005) Prenatal fetal sex diagnosis by detecting amelogenin gene in maternal plasma. Prenat. Diagn., 25, 577-581.

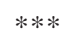

